\title{
The Influence Of Service Quality On Customer Satisfaction In Surabaya Tourist Destinations During The Covid-19 Pandemic
}

\author{
Yuniawati ekaningrum ${ }^{1)}$, Fredianaika Istanti ${ }^{2 *}$, Evada El Ummah Khoiro ${ }^{3)}$ \\ 1) Hospitality,Politeknik NSC Surabaya, Indonesia \\ 2) Business Administration,Politeknik NSC Surabaya, Indonesia \\ 3) International Marketing Management,Politeknik NSC Surabaya, Indonesia \\ *Coresponding Author \\ Email : fredianaika@gmail.com
}

\begin{abstract}
The long-term goal of the study is to find out if the tourism industry can survive the Covid-19 pandemic while still prioritizing the quality of services in accordance with health protocols. The type of research is descriptive analysis with a quantitative approach. The population in the study was the visitors to three tourist destinations in Surabaya, namely the Submarine Museum, House of Sampoerna and Surabaya Zoo. The number of samples used was 100 respondents using accidental sampling techniques, namely respondents who were accidentally encountered at the time the questionnaire was distributed. The collected data was analyzed using multiple regression analysis with SPSS 23.0 software. The results showed that the variables of service quality (realibility, responsiveness, assurance, emphaty, and tangibles) have a positive and significant influence on tourist satisfaction.
\end{abstract}

Keywords: Service Quality, Satisfaction, Tourist Destination, covid-19

\section{INTRODUCTION}

The rapid development of tourism has been damaged by the Covid-19 virus that affects all aspects, the tourism element is no exception (Utkarsh \& Sigala, 2021). The problem that has arisen since the global pandemic Covid-19 is the limited visits of tourists or visitors who conduct tourist activities followed by transportation, accommodation and other tourism fields that limit their visits. Related to the above problems, the author intends to conduct research related to the quality of human resource services in this case are officers who work in tourist destinations during the Covid-19 pandemic. Destinations selected by researchers include Surabaya Zoo, Submarine Monument, and House of Sampoerna.

Visitors or tourists demand to receive good service, so that the manager of tourist destinations tries as much as possible to provide the best service (Su \& Teng, 2018), especially officers who directly interact with visitors or tourists so as to give them satisfaction, both in conducive conditions and when the situation is not conducive (Roslan et al., 2015). This condition requires tourist attractions to survive by limiting the number of tourists and implementing very strict health protocols (Lakshmi Singh et al., 2021). The attraction of tourist destinations is one of the factors that encourage someone to travel to an area (Zhang \& Dong, 2021).

Quality of service is a key factor in tourist satisfaction, especially for the tourism sector as a sustainable competitive advantage (Roslan et al., 2015). Analysis of service quality will test how the dimensions of reliability, responsiveness, assurance, emphaty, and tangibles affect 
tourist satisfaction. These five dimensions are widely known as SERVQUAL MODEL which is a tool to measure service quality (Nowacki, 2005). Reliability is the ability to provide satisfactory service, provide accurate information, and how friendly officers behave in handling complaints. Responsiveness is the behavior of officers or staff who are quick to respond in providing services to visitors. Assurance is the skill and ability of officers to communicate and convey appropriate knowledge about tourist attraction facilities politely (Pakdil \& Aydin, 2007). Emphaty is the approach and attention of officers in understanding the needs and interests of visitors. Tangibles are various physical facilities, including means of communication, environmental cleanliness, to the maintenance of tourist attraction facilities (Bigné et al., 2003).

Travelers who consider the tourist destinations services to be of good quality and they consider their visit to provide a positive experience will be more satisfied with the experience when visiting the attraction (Ali et al., 2021). Quality of service is a component that must be maintained and done without error to understand and meet the demands of service users. In addition, the quality of service should always be a priority because it is very important for the success of a business (Shokouhyar et al., 2020)

Research on the quality of service to the satisfaction of visitors of a tourist attraction has been widely done by several researchers. Service quality testing of satisfaction with responsiveness, tangible, emphaty, communications, and consumables dimensions at Angkor Wat in Cambodia, Borobudur Temple in Indonesia, and Historic City of Vigan in the Philippines. Research shows that overall visitors are satisfied with the quality of tourist services, with variable consumables, (Angkor Wat), communications (Borobudur), and consumables and emphatys (Vigan) as the strongest predictors influencing satisfaction (Laserna, 2021). Research in The Thousand Islands of Indonesia shows that customer satisfaction mediates quality of service to customer loyalty (Lesmana et al, 2021). Research with the 4D model of assurance-responsiveness, tangible facilities-empathy, reliability, and reliability-quality of directions is able to show significant and positive results for the quality of service and loyalty mediated imaging of tourist destination (Akroush, 2016).

Different results are shown by some of the studies below. The quality of service has a positive effect on the satisfaction of visitors to Fort Malborough, with variable responsiveness, assurance, and emphaty having a significant effect, while realibility and tangible have a positive but insignificant effect (Pratama, 2016). Test results in the hospitality sector in Iraq showed 4 dimensions of service quality, namely responsiveness, assurance, emphaty, and tangibles positively affect satisfaction, unless realibility negatively affects visitor satisfaction (Ali et al, 2021). Similar results were shown in a study conducted at Iran's Golestan Museum that there was no significant relationship between realibility and satisfaction, while assurance, responsiveness, and tangibles had a significant relationship as a factor of satisfaction of visitors who were overall children (Hosseini, 2021).

Other studies conducted with the same object showed mixed results. Research on the quality of service, infrastructure, and diversity of animals to the satisfaction of tourists at Surabaya Zoo gave significant positive results (Lathifa, 2019). The quality of service of Museum House of Sampoerna Surabaya with HISTOQUAL method to assess satisfaction shows tangible and communication variables to be the strongest predictors. The service at the museum is considered to be of sufficient quality through consumable, emphaty, and responsiveness variables (Isnaini, 2019). The decline in the number of visitors at the Surabaya Zoo over the last few years is allegedly due to the decline in the quality of public facilities and conservative rides. In the future, service quality development strategies must be developed in 
order to be able to bridge the perception and expectations of visitors so that optimal satisfaction can be achieved(Wallsten, 2015)). Based on the background and to see if there is a gap in the results of the study as outlined above, then the researcher is interested in conducting research with the title "The Influence of Service Quality on Customer Satisfaction in Surabaya Tourist Destinations During The Covid-19 Pandemic" (Case Study at Surabaya Zoo, House Of Sampoerna, Submarine Monument).

\section{RESEARCH METHODS}

The data collection technique used in this study was to use questionnaires distributed to tourists in three tourist destinations in Surabaya, namely Surabaya Zoo, Submarine Museum and House of Sampoerna. Each question item has five answers that respondents must fill out using the Likert scale. The population in this study was visitors in three tourist destinations in Surabaya (Surabaya Zoo, Submarine Museum, and House of Sampoerna). Sampling techniques use Accidental Sampling, which is a respondent who coincidentally meets with researchers and can be used as a sample. The number of respondents used in this study amounted to 100 respondents. The data that has been obtained is processed using SPSS 23.0 Software to find out how much influence each variable has.

\section{RESULTS AND DISCUSSION}

\section{Validity and Reliability Testing}

By using valid and reliable instruments in data collection, it is expected that the results of the study will be valid and reliable. So a valid and reliable instrument is an absolute requirement to get valid and reliable research results. Valid means that the instrument can be used. The results of the validity and reliability tests of the indicators in this study all use SPSS 23.0 program tools.

In this study, validity testing was conducted on 100 respondents based on significance $<0.05$. The validity test is carried out by comparing the value of $r$-value (corrected item total correlations) with the value of the r-table. The value of r-table can be known by looking at the table with adjusted to the value of the degree of freedom (df) which is the number of samples (N)-2, in the study using a sample of 100 respondents so that the r-table uses one tail from df (N2) which is $100-2=98$ with probability ( $\mathrm{p}$-value $5 \%$ ) is 0.198 . The assumption is that if the $\mathrm{r}$ value (positive) is greater than the r-table then the question item can be assumed to be valid. Conversely, if the r-count is smaller than the r-table then the question item is assumed to be invalid.

\begin{tabular}{|c|c|c|}
\hline No. & $\begin{array}{l}\text { Question } \\
\text { Item A }\end{array}$ & Result \\
\hline 1. & $\bar{X} 1_{1}$ & Valid \\
\hline 2. & $\mathrm{X} 1_{2}$ & Valid \\
\hline 3. & $\mathrm{X} 1_{3}$ & Valid \\
\hline 4. & $\mathrm{X} 2_{1}$ & Valid \\
\hline 5. & $\mathrm{X} 2_{2}$ & Valid \\
\hline 6. & $\mathrm{X} 2_{3}$ & Valid \\
\hline 7. & $\mathrm{X} 3_{1}$ & Valid \\
\hline
\end{tabular}




\begin{tabular}{lll}
\hline $\mathbf{8 .}$ & $\mathrm{X} 3_{2}$ & Valid \\
$\mathbf{9 .}$ & $\mathrm{X} 3_{1}$ & Valid \\
$\mathbf{1 0 .}$ & $\mathrm{X} 4_{1}$ & Valid \\
$\mathbf{1 1}$. & $\mathrm{X} 4_{2}$ & Valid \\
$\mathbf{1 2}$ & $\mathrm{X} 5_{1}$ & Valid \\
$\mathbf{1 3}$ & $\mathrm{X} 5_{2}$ & Valid \\
$\mathbf{1 4}$. & $\mathrm{X} 5_{3}$ & Valid \\
$\mathbf{1 5}$ & $\mathrm{X} 5_{4}$ & Valid \\
\hline
\end{tabular}

\section{Reliability}

Table 2. Variable Reliability Test X1, X2, X3, X4 and Y

\begin{tabular}{llccl}
\hline No. & Variabel & $\begin{array}{c}\text { Cronbach } \\
\text { Alpha }\end{array}$ & Alpha & Keterangan \\
\hline 1. & $\left(\mathrm{X}_{1}\right)$ & 0,687 & 0,6 & Reliabel \\
2. & $\left(\mathrm{X}_{2}\right)$ & 0,871 & 0,6 & Reliabel \\
3. & $\left(\mathrm{X}_{3}\right)$ & 0,776 & 0,6 & Reliabel \\
$\mathbf{4 .}$ & $\left(\mathrm{X}_{4}\right)$ & 0,667 & 0,6 & Reliabel \\
\hline $\mathbf{5 .}$ & $(\mathrm{Y})$ & $\mathbf{0 , 7 8 6}$ & $\mathbf{0 , 6}$ & Reliabel \\
\hline
\end{tabular}

Based on the table above, it can be concluded that the five variables used in this study are reliable because the Cronbach Alpha value of each variable is greater than 0.6. So it can be concluded that all question items used in the questionnaire are reliable and the resulting data is accurate.

\section{Multiple Linear Regression Analysis}

The results of multiple linear regression analysis is as below:

Table 3

Regression Results

\begin{tabular}{|c|c|c|c|c|c|c|c|}
\hline Model & $\begin{array}{l}\text { Unstandardize } \\
\text { d Coefficients }\end{array}$ & & $\begin{array}{c}\text { Standardized } \\
\text { Coefficients }\end{array}$ & $\bar{t}$ & Sig & $\begin{array}{c}\text { Collinearity } \\
\text { Statictics }\end{array}$ & \\
\hline & $\bar{B}$ & $\begin{array}{l}\text { Std. } \\
\text { Eror }\end{array}$ & Beta & & & Tolerance & Vif \\
\hline Constant & 11.876 & 2.088 & & 5.576 & .000 & & \\
\hline Tangible & .259 & 0.85 & .149 & 3.145 & .002 & .879 & $\begin{array}{l}1.1 \\
47\end{array}$ \\
\hline Reliability & .226 & .108 & .119 & 2.256 & .000 & .714 & $\begin{array}{l}1.1 \\
29\end{array}$ \\
\hline Responsiveness & .476 & .082 & .276 & 5.487 & .000 & .878 & $\begin{array}{l}1.1 \\
78\end{array}$ \\
\hline Assurance & .289 & .109 & .104 & 2.277 & .001 & .869 & $\begin{array}{l}1.1 \\
47\end{array}$ \\
\hline Emphaty & .257 & .107 & .108 & 2.167 & .000 & .813 & $\begin{array}{l}1.2 \\
56\end{array}$ \\
\hline
\end{tabular}

From the results of regression calculations, the following equation is obtained: $\mathrm{Y}=11,876$ $+0.259 \mathrm{X} 1+0.226 \mathrm{X} 2+0.476 \times 3+0.289 \mathrm{X} 4+0.257 \mathrm{X} 5$. Which means the constant value shows a positive result, then if it is not influenced by tangibles, reliability, responsiveness, assurance and emphaty variables then the tourist satisfaction variable does not change. Of the five variables tested that most dominantly affect visitor satisfaction is responsiveness with a 
coefficient of 0.476 . The second dominant variable is the Assurance variable with a coefficient of 0.289 . The third largest is the tangibles variable with a coefficient of 0.259 . Next is the emphaty variable of 0.257 and the variable with the smallest coefficient value is the reliability variable of 0.226 . The five variables, namely tangibles, reliability, responsiveness, assurance and emphaty, positively affect visitor satisfaction in three tourist destinations in Surabaya (Surabaya Zoo, Submarine Museum, and House of Sampoerna).

From the results of the test-t found that the five variables namely tangibles, reliability, responsiveness, assurance and emphaty have a significance level of less than 0.05 . The dominant variable affecting the independent variable is the responsiveness variable. Which means that variable resposiveness is the strongest predictor that affects visitor satisfaction in three tourist destinations in Surabaya.

\section{Hypothesis Testing}

\section{The Influence of Tangible on Satisfaction}

The test results on hypothesis 1 showed that there was a positive and significant influence on variable X1 (Tangibles) on visitor satisfaction in three tourist destinations in Surabaya. The results showed that visitor satisfaction in three tourist destinations in Surabaya, influenced by tangibles, that tourist destination facilities affect visitor satisfaction and must have a measurable standard.

\section{The Influence of Reliability on Satisfaction}

The results of hypothesis 2 tests showed that there was a positive and significant influence of variable X2 (Reliability) on visitor satisfaction in three tourist destinations in Surabaya. The results showed that visitor satisfaction in three tourist destinations in Surabaya, based on reliability factors, that the services provided to visitors are in accordance with the expectations of visitors.

\section{The Influence of Responsiveness on Satisfaction}

The results of hypothesis 3 tests showed that there was a positive and significant influence of variable X3 (Resposiveness) on visitor satisfaction in three tourist destinations in Surabaya. The results showed that visitor satisfaction in three tourist destinations in Surabaya, based on tangible factors, that officers were quick to respond in providing services to visitors during the Covid-19 pandemic..

\section{The Influence of Assurance on Satisfaction}

The results of hypothesis 4 tests showed that there was a positive and significant influence on variable X4 (Assurance) on visitor satisfaction in three tourist destinations in Surabaya. The results showed that visitor satisfaction in three tourist destinations in Surabaya, based on the Assurance factor, that the staff is friendly and polite when serving visitors.

\section{The Influence of Emphaty on Satisfaction}

The results of hypothesis 5 tests showed that there was a positive and significant influence of variable X5 (Emphaty) on visitor satisfaction in three tourist destinations in Surabaya. The results showed that visitor satisfaction in three tourist destinations in Surabaya, based on tangible factors, that the staff had done good communication and could understand what visitors needed during their visit during the Covid-19 pandemic.

\section{F-test}

The F-test is used to test the influence of independent variables on dependent variables 
simultaneously. The results of the F-test if associated with the proposed hypothesis can be seen in the table below::

Table 4. Results of Simultaneous Regression Analysis (F-Test)

ANOVA $^{\text {b }}$

\begin{tabular}{lllllll}
\hline Model & Sum & of & \multicolumn{1}{c}{ d } & \multicolumn{1}{c}{ Mean } & F & Sig. \\
\hline $\mathbf{1}$ & Regressio & 1877.189 & 5 & 375.633 & 22. & $\mathbf{0 0 0}$ \\
Residual & 6583.338 & 396 & 16.791 & & \\
\hline \multicolumn{2}{c}{ Total } & $\mathbf{8 4 5 0 . 7 6 5}$ & $\mathbf{3 9 8}$ & & & \\
\hline
\end{tabular}

a. Predictors: (Constant), tangible,reliability,responsiveness,assurance,emphaty

b. Dependent Variable: kepuasan

Source : Data processed, 2021

Simultaneous testing of the influence of independent variables on dependent variables is performed using the F-test. The statistical calculations show the value of F-value $=22.678$ with significance of $0.000<0.05$. This means that simultaneously there is a significant influence of tangible, reliability, responsiveness, assurance and emphaty on satisfaction.

\section{Coefficient of Determination $\left(\mathbf{R}^{2}\right)$}

The coefficient of determination $\left(\mathrm{R}^{2}\right)$ essentially measures how far the model's ability to explain variations in dependent variables is. The coefficient of determination is between zero and one (Ghozali, 2011). The coefficient values of determination can be seen in the table below::

Table 5. Coefficient of determination (R2)

\begin{tabular}{|c|c|c|c|c|c|c|c|c|c|}
\hline & & & & Mode & imma & & & & \\
\hline \multirow{2}{*}{$\begin{array}{c}\text { Mode } \\
1\end{array}$} & \multirow[t]{2}{*}{$\overline{\mathbf{R}}$} & \multirow{2}{*}{$\begin{array}{c}\mathbf{R} \\
\text { squar } \\
\mathbf{e}\end{array}$} & \multirow{2}{*}{$\begin{array}{c}\begin{array}{c}\text { Adjuste } \\
\text { d }\end{array} \\
\text { R }\end{array}$} & \multirow{2}{*}{$\begin{array}{c}\text { Std. } \\
\text { Error of } \\
\text { the } \\
\text { Estimat } \\
\text { e }\end{array}$} & \multicolumn{5}{|c|}{ Change Statistics } \\
\hline & & & & & $\begin{array}{l}\mathrm{R} \\
\text { Square } \\
\text { Chang } \\
\mathrm{e}\end{array}$ & $\begin{array}{l}\text { F } \\
\text { Chang } \\
\text { e }\end{array}$ & $\begin{array}{l}\mathrm{df} \\
1\end{array}$ & $\begin{array}{l}\text { Df } \\
2\end{array}$ & $\begin{array}{l}\text { Sig. } \\
\text { F.Chang } \\
\text { e }\end{array}$ \\
\hline 1 & $\begin{array}{l}.48 \\
1\end{array}$ & .524 & .213 & 4.08766 & .224 & 22.427 & 5 & 395 & .000 \\
\hline
\end{tabular}

a. Predictors: (Constant), tangible, reliability, responsiveness ,assurance dan emphaty

b. Dependent Variable: Kepuasan

Source : Data processed, 2021

The calculations results using the SPSS program can be known that the coefficient of determination (adjusted $\mathrm{R}^{2}$ ) obtained is 0.524 . This means that $52.4 \%$ of visitor satisfaction can be explained by tangible, reliability, responsiveness, assurance and emphaty variable while the remaining $47.6 \%$ is influenced by other factors. Other factors not included in the study can also affect, but there are many other factors that affect it. 


\section{CONCLUSION}

The quality of service is an important factor in assessing satisfaction, as it stimulates positive visitor behavior towards tourist destinations, such as revisiting (Laserna, 2021), increased tourist loyalty and positive word-of-mouth (Su \& Teng, 2018). Based on the analysis results and discussion in this study, it can be concluded that the tangible variable has a positive effect on satisfaction, the reliability variable has a positive influence on satisfaction, the responsiveness variable has a positive influence on satisfaction, the assurance variable has a positive influence on satisfaction, and the empathy variable has a positive influence on satisfaction.

The simultaneous influence of all independent variables (tangible, reliability, responsiveness, assurance, and empathy) on satisfaction shows significant results. The test results are in accordance with the opinion of other studies that overall service quality affects tourist satisfaction ((Park et al., 2020); (Donnelly, 2019); (Lakshmi Singh et al., 2021); Nonthapot dan Nasoontorn, 2020; (Ali et al., 2021); Sirait, 2015; Yulianingsih 2018). The results of this research are different from other studies ((Roslan et al., 2015); (Silalahi et al., 2017)), which shows that only reliability negatively affects visitor satisfaction and does not effectively form satisfaction. Lastly, visitor satisfaction can be explained by variable tangible, reliability, responsiveness, assurance and emphaty but there are other factors that are not included in the study can affect it.

\section{REFERENCES}

Ali, B. J., Gardi, B., Othman, B. J., Ahmed, S. A., Ismael, N. B., Hamza, P. A., Aziz, H. M., Sabir, B. Y., Sorguli, S., \& Anwar, G. (2021). Hotel Service Quality: The Impact of Service Quality on Customer Satisfaction in Hospitality. International Journal of Engineering, Business and Management, 5(3), 14-28. https://doi.org/10.22161/ijebm.5.3.2

Bigné, J. E., Martínez, C., Miquel, M. J., \& Andreu, L. (2003). SERVQUAL Reliability and Validity in Travel Agencies. Annals of Tourism Research, 30(1), 258-262. https://doi.org/10.1016/S0160-7383(01)00090-1

Donnelly, R. (2019). Aligning knowledge sharing interventions with the promotion of firm success: The need for SHRM to balance tensions and challenges. Journal of Business Research, 94, 344-352. https://doi.org/10.1016/j.jbusres.2018.02.007

Lakshmi Singh, A., Jamal, S., \& Suhail Ahmad, W. (2021). Impact assessment of lockdown amid COVID-19 pandemic on tourism industry of Kashmir Valley, India. Research in Globalization, 3, 100053. https://doi.org/10.1016/j.resglo.2021.100053

Laserna, M. G. H. (2021). Service Quality Assessment Of Selected Heritage Sites Incambodia, Indonesia, And Philippines By Tourists Towards The Development Of Service Delivery Improvement Plan. 7(4). https://doi.org/10.5281/zenodo.4721330

Pakdil, F., \& Aydın, Ö. (2007). Expectations and perceptions in airline services: An analysis using weighted SERVQUAL scores. Journal of Air Transport Management, 13(4), 229237. https://doi.org/10.1016/j.jairtraman.2007.04.001 
Park, S., Lee, J.-S., \& Nicolau, J. L. (2020). Understanding the dynamics of the quality of airline service attributes: Satisfiers and dissatisfiers. Tourism Management, 81, 104163. https://doi.org/10.1016/j.tourman.2020.104163

Roslan, N. A. A., Wahab, E., \& Abdullah, N. H. (2015). Service Quality: A Case Study of Logistics Sector in Iskandar Malaysia Using SERVQUAL Model. Procedia - Social and Behavioral Sciences, 172, 457-462. https://doi.org/10.1016/j.sbspro.2015.01.380

Shokouhyar, S., Shokoohyar, S., \& Safari, S. (2020). Research on the influence of after-sales service quality factors on customer satisfaction. Journal of Retailing and Consumer Services, 56, 102139. https://doi.org/10.1016/j.jretconser.2020.102139

Silalahi, S. L. B., Handayani, P. W., \& Munajat, Q. (2017). Service Quality Analysis for Online Transportation Services: Case Study of GO-JEK. Procedia Computer Science, 124, $487-$ 495. https://doi.org/10.1016/j.procs.2017.12.181

Su, Y., \& Teng, W. (2018). Contemplating museums' service failure: Extracting the service quality dimensions of museums from negative on-line reviews. Tourism Management, 69, 214-222. https://doi.org/10.1016/j.tourman.2018.06.020

Utkarsh, \& Sigala, M. (2021). A bibliometric review of research on COVID-19 and tourism: Reflections for moving forward. Tourism Management Perspectives, 40, 100912. https://doi.org/10.1016/j.tmp.2021.100912

Wallsten, S. (2015). The Competitive Effects of the Sharing Economy: How is Uber Changing Taxis? Technological Policy Institute, June.

Zhang, J., \& Dong, L. (2021). Image Monitoring and Management of Hot Tourism Destination Based on Data Mining Technology in Big Data Environment. Microprocessors and Microsystems, 80, 103515. https://doi.org/10.1016/j.micpro.2020.103515 